American Journal of Applied Sciences 6 (3): 529-533, 2009

ISSN 1546-9239

(C) 2009 Science Publications

\title{
Effect of Storage Temperature on the Stability of Phytonutrients in Palm Concentrates
}

\author{
${ }^{1,2}$ K. Chandrasekaram, ${ }^{2}$ M.H. Ng, ${ }^{2}$ Y.M. Choo and ${ }^{1}$ C.H. Chuah \\ ${ }^{1}$ Department of Chemistry, Faculty of Science, University of Malaya, 50603 Kuala Lumpur, Malaysia \\ ${ }^{2}$ Malaysian Palm Oil Board, 6, Persiaran Instates, Bandar Baru Bangi, \\ 43000 Kajang, Selangor, Malaysia
}

\begin{abstract}
Palm phytonutrient concentrates; a valuable by-product from the production of palm biodiesel contains an abundance of natural phytonutrients such as carotenes, vitamin E, sterols, squalene and coenzyme Q. The present research described the concentration of phytonutrients that obtained from palm biodiesel production. The concentration of phytonutrients available in palm phytonutrients concentrate is ten times higher than in crude palm oil. The most prevalent of the phytonutrients are carotenes (23,000-24,000 ppm), vitamin E (14,000-15,000 ppm), sterols (15000$16,000 \mathrm{ppm})$ and squalene $(2,900-3,100 \mathrm{ppm})$. These phytonutrients being extremely sensitive to temperature in nature suffer up to $70 \%$ of deterioration to their concentration at room temperature. The phytonutrients in the refrigerated samples however were able to retain most of their concentration with a minimal loss of less than $10 \%$ to their concentration.
\end{abstract}

Keywords: Carotenes, phytonutrients, palm, storage, temperature, vitamin E

\section{INTRODUCTION}

Palm oil has always been an important economic commodity of Malaysia. Currently palm oil is creating waves in the world market for its undeniable role in the field of biodiesel production ${ }^{[1,2]}$. This widely consumed vegetable oil is also a great source of naturally occurring phytonutrients ${ }^{[2,3]}$. The most prevalent phytonutrients found in crude palm oil are carotenes (500-700 ppm), vitamin E (600-1000 ppm), sterols (250-620 ppm), squalene (200-600 ppm) and coenzyme $\mathrm{Q}(10-80 \mathrm{ppm})^{[4-9,18]}$.

Palm phytonutrients concentrate is one of the byproducts obtained during the production of palm biodiesel. In the production of palm biodiesel, crude palm oil is transesterified in an alcoholic medium with an alkaline catalyst to give red coloured alkyl esters. These red coloured alkyl esters could be used as fuel, however, it was found that they were actually rich in natural palm phytonutrients. Molecular distillation had been used to separate the natural palm phytonutrients and esters without any loss or change in the product $^{[1,2,16,17]}$. The distilled esters, a colour less liquid were then used for the production of biodiesel. The palm phytonutrients concentrate that was collected as a thick red concoction can be used in the treatment of major diseases such as cancer and heart diseases ${ }^{[1,20]}$. For instance, phytonutrients namely carotenes, vitamin
E, co-enzyme Q are vital substances used in the prevention and treating of cancers and various cardiovascular related ailments ${ }^{[15,20]}$. However, phytonutrients that are biologically active are extremely sensitive towards heat and light ${ }^{[1,12,15,19]}$. Overexposure and improper not result in major losses in the concentration of the phytonutrients ${ }^{[10-15]}$.

Therefore, this research studied the composition of selected phytonutrients that presented in crude palm oil and palm phytonutrients concentrate. The effect of storage temperature on the stability of the palm phytonutrients concentrate was also being investigated.

\section{MATERIALS AND METHOD}

Crude Palm Oil (CPO) was obtained from Malaysian Palm Oil Board (MPOB) experimental mill and Palm Phytonutrients Concentrate (PPC) was obtained from Carotino Sdn Bhd (Malaysia). All solvents used were of chromatographic or analytical grade and purchased from Merck (Darmstadt, Germany) and J.T. Baker (Phillipsburg, NJ). All standards were purchased from Sigma-Aldrich (Malaysia).

Sample preparation: Preparation of unsaponifiables of palm phytonutrients concentrate. 2.00 grams of palm phytonutrients concentrate was saponified at $60^{\circ} \mathrm{C}$ with

Corresponding Author: K. Chandrasekaram, Department of Chemistry, Faculty of Science, University of Malaya, 50603 Kuala Lumpur, Malaysia 
$5 \mathrm{~mL}$ of $50 \%(\mathrm{w} / \mathrm{w})$ potassium hydroxide solution and $20 \mathrm{~mL}$ ethanol. The mixture was refluxed in the dark 1 $\mathrm{h}$. The reacted mixture was then extracted 5 times with hexane until a colourless organic layer was obtained. The extracted organic layer was then washed with distilled water until the waste water was tested neutral in phenolphthalein. Excess solvent was evaporated and the sample was then stored in a cold, dry place. Sample was labeled as Unsap PPC (unsaponifiables of palm phytonutrients concentrate).

Analysis of carotenes: A known amount of CPO was dissolved in hexane in a $50 \mathrm{~mL}$ volumetric flask. Hexane was used as the blank solution to monitor the baseline. A Hitachi Ultraviolet Spectrometer was used to measure the ultraviolet (UV) absorbance value. The UV absorbance was measured at $446 \mathrm{~nm}^{[11,12]}$. Using the results obtained, the concentration of carotenes in the sample was calculated, using the formula below:

$$
[\text { Carotene }]=\frac{383 \times \text { Absorbance }(446 \mathrm{~nm}) \times \operatorname{Volume}(\mathrm{mL})}{100 \times \text { sample weight }(\mathrm{g})}
$$

Where:

Carotene $=$ Concentration of carotenes in ppm

Volume $=$ Volume of volumetric flask

$383=$ Diffusion coefficient

The same procedures were repeated with PPC and Unsap PPC.

Analysis of vitamin E: A known amount of CPO was weighed and dissolved with hexane in a $1.0 \mathrm{~mL}$ vial. The prepared CPO sample was then injected into a High Performance Liquid Chromatography (HPLC) system. A Waters HPLC with a fluorescence detector (excitation at $295 \mathrm{~nm}$ and emission at $325 \mathrm{~nm}$ ) and a Zorbax analytical silica column $(25 \mathrm{~cm} \times 4.6 \mathrm{~mm}$ ID, stainless steel, $5 \mu \mathrm{m}$ ) was used to analyses Vitamin E. The mobile phase used was hexane: tetrahydrofuran: isopropanol (1000: $60: 4 \mathrm{v} / \mathrm{v} / \mathrm{v})$ at a flowrate of $1.0 \mathrm{~mL}$ $\min ^{-1[12]}$. A standard sample with $\alpha$-tocopherol was also prepared using similar method. Concentration of vitamin $\mathrm{E}$ in $\mathrm{CPO}$ was calibrated using authentic standards. The procedures were repeated with PPC and Unsap PPC.

Analysis of squalene and sterols: A known amount of CPO was weighed in a $1.5 \mathrm{ml}$ vial and dissolved in a mixture of $0.2 \mathrm{~mL}$ triacontane and $1.3 \mathrm{~mL}$ of N,Obis(trimethylsilyl) trifluoroacetamide (BSTFA) in dichloromethane (DCM). BSTFA in DCM was prepared by adding $0.3 \mathrm{~mL}$ BSTFA into $1.2 \mathrm{~mL}$ DCM. The prepared CPO was tightly capped and silylated for $2 \mathrm{~h}$ at $60^{\circ} \mathrm{C}$. Triacontane was used as the internal standard and BSTFA was used as the derivatising agent. After silylation, the prepared $\mathrm{CPO}$ was injected into a Gas Chromatography with a Flame Ionization Detector (GC-FID) system. A Hewlett Packard 5860 Series II Plus GC with a flame ionization detector was used with a BPX-5 GC capillary column $(15 \mathrm{~m} \times 0.32$ $\mathrm{mm}$ ID BPX $5 \times 0.25 \mu \mathrm{m})$. GC conditions were as follows: injector temperature, $45^{\circ} \mathrm{C}$, detector temperature, $370^{\circ} \mathrm{C}$, initial oven temperature, $100^{\circ} \mathrm{C}$, initial holding time, $1 \mathrm{~min}$, ramping rate, $10^{\circ} \mathrm{C} \mathrm{min}^{-1}$, final temperature, $360^{\circ} \mathrm{C}$, final holding time, $16 \mathrm{~min}$, carrier gas (He) flow rate, $2 \mathrm{~cm}^{3} \mathrm{~min}^{-1}$, column pressure, $14.5 \mathrm{psi}$, injection volume, $1 \mathrm{~mL}^{[18]}$. A standard sample of squalene and sterols were also prepared using similar method. Concentration of sterols and squalene in CPO was calibrated using authentic standards. The procedures were repeated with PPC and Unsap PPC.

Storage conditions: Two sets of samples consisting of 3 vials each of Unsap PPC were prepared. One set was placed at room temperature with a temperature range of $28-32^{\circ} \mathrm{C}$. The other set was refrigerated at a temperature between $-14-18^{\circ} \mathrm{C}$. Each vial was monitored for its phytonutrients content once a month for 3 consecutive months. A mean value was calculated from these 3 vials.

\section{RESULTS AND DISCUSSION}

The concentration of selected phytonutrients present in CPO and PPC is as shown in Table 1. The presence of phytonutrients in Palm Phytonutrients Concentrate (PPC) was found to be ten times higher than that in Crude Palm Oil (CPO). The percentage of phytonutrients in PPC was approximately $10 \%$ of its weight while they were only $1 \%$ of its weight in CPO. This was mainly due to a major portion of glycerides and esters were removed during the production of methyl esters and thus, the presence of phytonutrients became more prevalent in PPC.

$\mathrm{CPO}$ has a bulk concentration of glycerides and esters with $90 \%$ of CPO made up of triglycerides. Though transesterification and molecular distillation can remove a bulk of the glycerides and esters that present, a small amount still remains intact in PPC. Saponification process is necessary to further separate the unsaponifiables or phytonutrients in crude palm oil or palm phytonutrients concentrate from the glycerides and esters. It allows an increase in the concentration of 
Am. J. Applied Sci., 6 (3): 529-533, 2009

Table 1: Concentration of selected phytonutrients in Crude Palm Oil (CPO) and Palm Phytonutrients Concentrate (PPC)

\begin{tabular}{lll}
\hline & Concentration (ppm) & \\
& CPO & PPC \\
\hline Carotenes & 530 & 23710 \\
Vitamin E & 1020 & 14640 \\
Sterols & 910 & 15780 \\
Squalene & 440 & 3020 \\
\hline
\end{tabular}

$\mathrm{CPO}=$ crude palm oil, $\mathrm{PPC}=$ palm phytonutrients concentrate

Table 2: Concentration of selected phytonutrients in unsaponifiables of crude palm oil (Unsap CPO) and unsaponifiables of palm phytonutrients concentrate (Unsap PPC)

Concentration (ppm)

\begin{tabular}{lll} 
& Unsap CPO & Unsap PPC \\
\hline Carotenes & 19570 & 209880 \\
Vitamin E & 39290 & 78660 \\
Sterols & 32430 & 30500 \\
Squalene & 2770 & 8110 \\
\hline Unsap CPO = unsaponifiables of crude palm oil, & Unsap PPC = \\
unsaponifiables of palm phytonutrients concentrate &
\end{tabular}

the phytonutrients in both of the CPO and PPC (Table 2). The presence of phytonutrients in palm phytonutrients concentrate was higher and the concentration was further increased when palm phytonutrients concentrate was saponified. The saponification process managed to minimize the interference from glycerides and esters and also enable a better environment for the analysis of phytonutrients.

Phytonutrients are naturally occurring bioactive compounds. These compounds have high affinity towards heat and light ${ }^{[8,11,12]}$. Usually normal room temperature itself is enough to cause the compounds to disintegrate ${ }^{[16,21]}$. Based on these theories, the samples (Unsap PPC) were analysed under 2 different temperatures. A set of samples were stored at room temperature with a temperature range between $28-32^{\circ} \mathrm{C}$. Another set of samples were refrigerated at a temperature between -14 to $-18^{\circ} \mathrm{C}$. Table 3 showing of the percentage of deterioration in the concentration of selected phytonutrients in Unsap PPC after 3 months of storage at room temperature and refrigeration.

Figure 1 and 2 gives a clear picture on the loss in the concentration of selected phytonutrients in Unsap PPC that occurred within the 3 months period. Figure 1 denotes the change in the concentration of the selected phytonutrients in the samples stored at room temperature. All 4 selected phytonutrients suffer a loss in the concentration. Squalene is almost lost by the end of the third month. Vitamin E and sterols gradually lose their concentration by the month. Of the selected 4 phytonutrients, carotenes suffer the minimal loss in its concentration. This could be because oxidation of

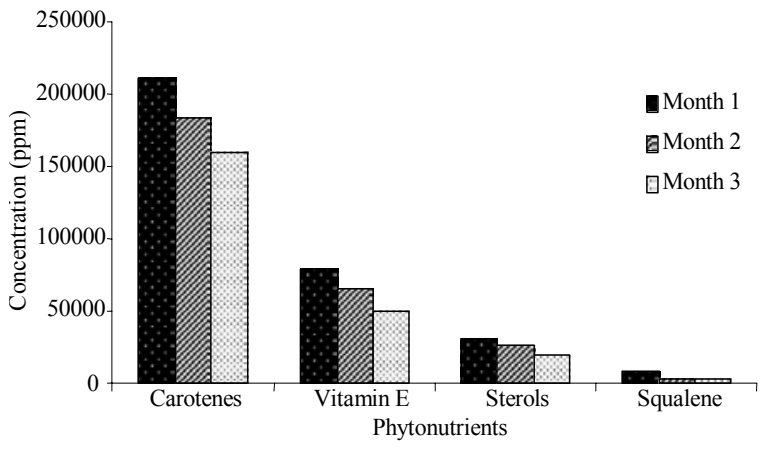

Fig. 1: Concentration of selected phytonutrients stored at room temperature approximately at $(30 \pm 2)^{\circ} \mathrm{C}$

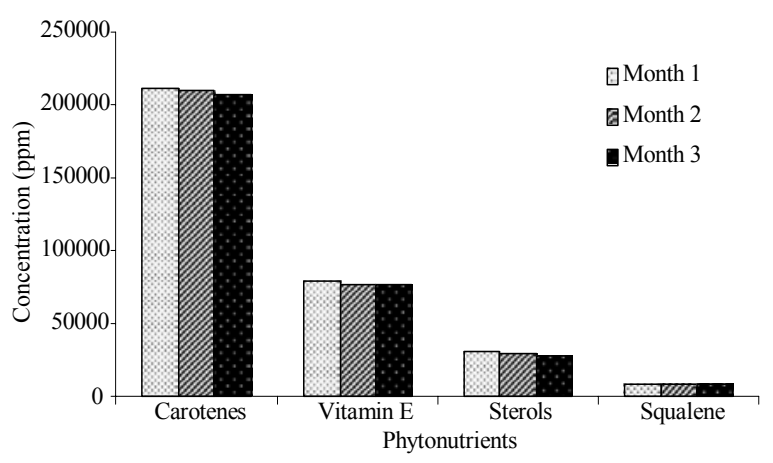

Fig. 2: Concentration of selected phytonutrients refrigerated at approximately $(-16 \pm 2)^{\circ} \mathrm{C}$

vitamin $\mathrm{E}$ started before carotenes and thus protected the carotenes from deterioration.

On the other hand, the changes in the concentration of the selected phytonutrients in the refrigerated samples was denoted. All the four selected phytonutrients suffered a loss in the concentration, however, by comparison with Figure 1 it could be seen to be minimal. The selected phytonutrients were still presented by the end of the third month. At the end of the storage period, the concentration of squalene was remained almost intact. The percentages of loss in the concentration were all well below $10.0 \%$.

The overall loss in the concentration of the four selected phytonutrients in Unsap PPC which occurred during the three months time span of this study was summarized in Table 4. The results showed that the loss of concentration in the selected phytonutrients occured in both samples. However, samples that stored at room temperature suffered a huge amount of loss compared to the refrigerated sample and squalene was almost completely lost. All the selected phytonutrients in the sample stored at room temperature disintegrated 
Am. J. Applied Sci., 6 (3): 529-533, 2009

Table 3: Percentage of deterioration in the concentration of selected phytonutrients in unsap palm phytonutrients concentrate after one month and two months of storage

\begin{tabular}{|c|c|c|c|c|c|c|c|c|}
\hline \multirow[t]{3}{*}{ Storage Condition } & \multicolumn{8}{|c|}{ Percentage of Deterioration (\%) } \\
\hline & \multicolumn{2}{|l|}{ Carotenes } & \multicolumn{2}{|l|}{ Vitamin E } & \multicolumn{2}{|l|}{ Sterols } & \multicolumn{2}{|l|}{ Squalene } \\
\hline & $\begin{array}{l}\text { After } 1 \text { month } \\
\text { storage }\end{array}$ & $\begin{array}{l}\text { After } 2 \text { month } \\
\text { storage }\end{array}$ & $\begin{array}{l}\text { After } 1 \text { montl } \\
\text { storage }\end{array}$ & $\begin{array}{l}\text { h After } 2 \text { month } \\
\text { storage }\end{array}$ & $\begin{array}{l}\text { After } 1 \text { month } \\
\text { storage }\end{array}$ & $\begin{array}{l}\text { After } 2 \text { month } \\
\text { storage }\end{array}$ & $\begin{array}{l}\text { After } 1 \text { month } \\
\text { storage }\end{array}$ & $\begin{array}{l}\text { After } 2 \text { month } \\
\text { storage }\end{array}$ \\
\hline $\begin{array}{l}\text { Room temperature } \\
(30 \pm 2)^{\circ} \mathrm{C}\end{array}$ & 12.8 & 24.4 & 15.9 & 36.9 & 12.2 & 36.3 & 59.8 & 72.6 \\
\hline Refrigerated $(-16+2)^{\circ} \mathrm{C}$ & 1.4 & 4.8 & 2.3 & 6.2 & 5.6 & 7.7 & 1.0 & 1.3 \\
\hline
\end{tabular}

Table 4: The percentage and total loss in the concentration of the selected phytonutrients in palm phytonutrients concentrate after 3 months storage

\begin{tabular}{|c|c|c|c|c|}
\hline & \multicolumn{4}{|l|}{ Storage condition } \\
\hline & \multicolumn{2}{|c|}{ Room temperature $(30 \pm 2)^{\circ} \mathrm{C}$} & \multicolumn{2}{|l|}{ Refrigerated $(-16 \pm 2)^{\circ} \mathrm{C}$} \\
\hline & Percentage of loss $(\%)$ & Loss of concentration (ppm) & Percentage of loss $(\%)$ & Loss of concentration (ppm) \\
\hline Carotenes & 24 & 51210 & 5 & 2910 \\
\hline Vitamin E & 37 & 29030 & 6 & 2930 \\
\hline Sterols & 36 & 11070 & 8 & 2350 \\
\hline Squalene & 73 & 5890 & 1 & 110 \\
\hline
\end{tabular}

considerably compared to their concentration at the start of the study. On contrary, the refrigerated samples recorded only a minimal amount of loss that not exceeding $10 \%$ of the starting concentration of each selected phytonutrients. Surprisingly, squalene in the refrigerated samples was almost intact. The concentration of the other selected phytonutrients was almost equally intact and showed far more stable than the sample that stored at room temperature.

\section{CONCLUSION}

Palm phytonutrients concentrate had been proved to have a far higher concentration of phytonutrients than in crude palm oil. This makes palm phytonutrients concentrate an ideal starting material for palm phytonutrients based studies and production. However, palm phytonutrients especially carotenes, vitamin E, squalene and sterols are extremely sensitive towards temperature. Of so, these nutritionally valuable phytochemicals should always be refrigerated and stored in cold, dry places to prevent their loss in concentration.

\section{ACKNOWLEDGMENT}

This research is supported by the Malaysian Palm Oil Board Postgraduate Research Grant.

\section{REFERENCES}

1. Ooi, C.K., Y.M. Choo, S.C. Yap, A.G. Ma and Yusof Basiron, 1993. Production of palm oil carotene concentrate. Proceedings of the 1993 PORIM International Palm Oil Congress 'Update and Vision' - Chemistry and Technology. pp: 177184. http://palmoilis.mpob.gov.my/Netacgi/nphbrs.exe?SECT $5=$ OPAC $\&$ SECT $6=$ HITOFF $\& d=$ OP $\mathrm{AC} \& \mathrm{p}=3 \& \mathrm{u}=/$ main. $h \mathrm{tml} \& \mathrm{r}=48 \& \mathrm{f}=\mathrm{G} \& \mathrm{l}=20 \& \mathrm{~s} 1=\mathrm{p}$ hytonutrients+concentrate

2. Choo, Y.M., L.L.N. Harrison, C.W. Puah, M.H. Ng, S.C. Bong, A.N. Ma and Yusof Basiron, 2002. Production of phytonutrients (carotenes, vitamin $\mathrm{E}$, sterols, squalene, co-enzyme $\mathrm{Q}$ and phospholipids) from palm methyl esters. MPOB Information Series No. 168. ttp://palmoilis.mpob.gov.my/ etacgi/nphbrs.exe?SECT5=OPAC\&SECT $6=$ ITOFF $\& \mathrm{~d}=\mathrm{OPAC} \& \mathrm{p}=1 \& \mathrm{u}=/$ main $. h \mathrm{tml} \& \mathrm{r}=15 \& \mathrm{f}=$ G\&l=20\&s1=phytonutrients

3. Choo, Y.M., M.H. Ng, A.N. Ma and Yusof Basiron, 2002. Production of individual carotene, tocols and cholesterol free sterol from crude palm oil. MPOB Information Series No.167. http://palmoilis.mpob.gov.my/Netacgi/nphbrs.exe?SECT $5=$ OPAC $\&$ SECT $6=$ HITOFF $\& d=O P$ $\mathrm{AC} \& \mathrm{p}=14 \& \mathrm{u}=/$ main. $h \mathrm{tm} l \& \mathrm{r}=271 \& \mathrm{f}=\mathrm{G} \& \mathrm{l}=20 \& \mathrm{~s} 1$ $=$ ng + mei + han 
4. Ab Gapor Md Top, Mohammad Sulong and Rosnah Mat Som, 2002. Production of phytosterols from palm fatty acid distillate. MPOB Information Series No. 185. http://palmoilis.mpob.gov.my /Netacgi/nph-brs.exe?SECT5=OPAC\&SECT6= HITOFF \&d=OPAC\&p=1\&u=/main.html\&r $=13 \& \mathrm{f}$ $=\mathrm{G} \& \mathrm{l}=20 \& \mathrm{~s} 1=$ phytosterols

5. Goh, S.H., Y.M. Choo and S.H.O Augustine 1997. Minor components in palm oil. Proceedings of 1987 International Oil Palm Conference. June 29July $\quad 1$, pp: 95-101. http://palmoilis.mpob.gov.my/Netacgi/nph-brs.exe ?SECT5=OPAC\&SECT6 $=$ HITOFF $\& d=$ OPAC $\& p$ $=4 \& \mathrm{u}=/$ main $. h \mathrm{tml} \& \mathrm{r}=75 \& \mathrm{f}=\mathrm{G} \& \mathrm{l}=20 \& \mathrm{~s} 1=$ minor $+\mathrm{c}$ onstituents

6. Ooi, C.K., 1999. Minor components of palm oil. PORIM Bull., 38: 29-32. http://palmoilis.mpob.gov.my/Netacgi/nph-brs.exe ?SECT $5=$ OPAC $\&$ SECT $6=$ HITOFF $\& d=$ OPAC $\& p$ $=3 \& \mathrm{u}=/$ main $. h \mathrm{tml} \& \mathrm{r}=46 \& \mathrm{f}=\mathrm{G} \& \mathrm{l}=20 \& \mathrm{~s} 1=0 \mathrm{oi}+\mathrm{che}$ ng+kiat

7. Chong, C.L. and M.R.M Jaais, 1995. Minor components of palm oil. Porim Palm Oil Tech. Bull., $\quad 1: \quad 6-7$. http://palmoilis.mpob.gov.my/Netacgi/nph-brs.exe ?SECT5=OPAC\&SECT6 $=$ HITOFF $\& d=$ OPAC $\& p$ $=3 \& \mathrm{u}=/$ main $\cdot h \mathrm{tml} \& \mathrm{r}=46 \& \mathrm{f}=\mathrm{G} \& \mathrm{l}=20 \& \mathrm{~s} 1=$ minor $+\mathrm{c}$ omponents

8. Ooi, C.K., 1995. Carotenes and palm oil. Palm Oil Tech. Bull., 1: 1-3. http://palmoilis.mpob.gov.my/Netacgi/nph-brs.exe ?SECT5=OPAC $\&$ SECT $6=$ HITOFF $\& d=$ OPAC $\& p$ $=2 \& \mathrm{u}=/$ main $. h \mathrm{tml} \& \mathrm{r}=40 \& \mathrm{f}=\mathrm{G} \& \mathrm{l}=20 \& \mathrm{~s} 1=0 \mathrm{oi}+\mathrm{che}$ ng+kiat

9. Goh, S.H., Y.M Choo and A.S.H. Ong, 1985. Minor constituents of palm oil. J. Amer. Oil Chem. Soc. 62: 237-240. DOI: 10.1007/BF02541384.

10. Ab Gapor Md Top, Wan Hasamudin Wan Hassan and Mohammad Sulong, 2000. Phytochemicals for nutraceuticals from the by-product of palm oil refining. Palm Oil Dev., 36: 17-19. http://palmoilis.mpob.gov.my/Netacgi/nph-brs.exe ?SECT5=OPAC\&SECT6=HITOFF \&d=OPAC\&p $=1 \& \mathrm{u}=/$ main $. h \mathrm{tml} \& \mathrm{r}=3 \& \mathrm{f}=\mathrm{G} \& \mathrm{l}=20 \& \mathrm{~s} 1=$ Phytoche micals

11. Choo, Y.M. and T.Y.P Bonnie, 2000. Valuable phytonutrients in commercial red palm olein. Palm Oil Dev., 32: 20-25. http://palmoilis.mpob.gov.my/Netacgi/nph-brs.exe ?SECT5=OPAC\&SECT6=HITOFF\&d=OPAC\&p $=1 \& \mathrm{u}=/$ main $. \mathrm{html} \& \mathrm{r}=4 \& \mathrm{f}=\mathrm{G} \& \mathrm{l}=20 \& \mathrm{~s} 1=$ bonnie
12. Choo, Y.M. and T.Y.P Bonnie, 2000. Valuable minor constituents of commercial red palm olein: carotenoids, vitamin E, ubiquinones and sterols. J. Oil Palm Res. 12: 14-24. http://palmoilis.mpob.gov.my/Netacgi/nph-brs.exe ?SECT5 $=$ OPAC $\&$ SECT $6=$ HITOFF $\& d=$ OPAC $\& p$ $=1 \& \mathrm{u}=/$ main $. h t m l \& \mathrm{r}=6 \& \mathrm{f}=\mathrm{G} \& \mathrm{l}=20 \& \mathrm{~s} 1=$ bonnie

13. Ng, M.H., Y.M Choo, A.N Ma, C.H. Chuah and Mohd Ali Hashim, 2006. Separation of coenzyme $\mathrm{Q}_{10}$ in palm oil by supercritical fluid chromatography. Am. J. Applied Sci., 3: 1929-1938. http://www.doaj.org/doaj?func $=$ abstract $\& \mathrm{id}=175628$

14. Ng, M.H., Y.M Choo, A.N Ma, C.H. Chuah and Mohd Ali Hashim, 2004. Separation of Vitamin E (tocopherol, tocotrienol and tocomonoenol) in Palm Oil. Lipids, 39: 1031-1035. DOI: 10.1007/s11745-004-1327-y

15. Choo, Y.M. and Yusof Basiron, 1996. Elaeis Oleifera Palm for the Pharmaceutical Industry. MPOB Information Series No. 60. http://palmoilis. mpob.gov.my/Netacgi/nph-brs.exe?SECT5=OPAC $\&$ SECT $6=$ HITOFF $\& \mathrm{~d}=$ OPAC $\& \mathrm{p}=7 \& \mathrm{u}=/$ main.htm $1 \& \mathrm{r}=125 \& \mathrm{f}=\mathrm{G} \& \mathrm{l}=20 \& \mathrm{~s} 1=$ pharmaceutical

16. Ooi, C.K., Y.M. Choo, S.C. Yap, Yusof Basiron and S.H.O Augustine, 1994. Recovery of carotenoids from palm oil. J. Amer. Oil Chem. Soc. 71: 423-426. DOI: 10.1007/BF02540524

17. Choo, Y.M., 2005. Recovery of palm phytonutrients. United States Patent 7141712. http://patft1.uspto.gov/netacgi/nph-Parser?Sect1= PTO2 \&Sect $2=$ HITOFF $\& p=1 \& u=\% 2$ Fnetahtml $\% 2$ FPTO $\% 2$ Fsearch-bool.html\&r=1\&f=G\&l=50\&co1 $=$ AND $\& \mathrm{~d}=$ PTXT $\& \mathrm{~s} 1=\% 22$ recovery + palm + phyton utrients\%22.TI.\&OS=TTL/

18. Harrison, L.L.N., C.W. Puah, Y.M. Choo, A.N. Ma, and C.H. Chuah, 2005. Simultaneous quantification of free fatty acids, free sterols, squalene, and acylglycerol molecular species in palm oil by high-temperature gas chromatographyflame ionization detection. Lipids 40: 523-528. DOI: 10.1007/s11745-005-1413-1.

19. Bonnie, T Y P and Y.M. Choo, 1999. Oxidation and thermal degradation of carotenoids. J. Oil Palm Res. 11: 62-78. http://palmoilis.mpob.gov.my/ Netacgi/nph-brs.exe?SECT5=OPAC\&SECT6= HITOFF $\& d=$ OPAC $\& \mathrm{p}=1 \& \mathrm{u}=/$ main. $h$ tml $\& \mathrm{r}=2 \& \mathrm{f}=$ G\&l=20\&s1=bonnie

20. Sundaram, K and N. Chandrasekharan, 1995. Minor components in edible oils and fats: their nutritional implications. Palm Oil Dev., 22: 22-26. http://palmoilis.mpob.gov.my/Netacgi/nph-brs.exe ?SECT5=OPAC\&SECT $6=\mathrm{HITOFF} \& \mathrm{~d}=\mathrm{OPAC} \& \mathrm{p}$ $=2 \& \mathrm{u}=/$ main $\cdot h t \mathrm{ml} \& \mathrm{r}=38 \& \mathrm{f}=\mathrm{G} \& \mathrm{l}=20 \& \mathrm{~s} 1=$ minor $+\mathrm{c}$ omponents 